特集 4

胃癌の術前画像診断によるリンパ節転移診断能の検討

大阪医科大学一般・消化器外科, 北出胃腸病院*

\begin{tabular}{|c|c|c|c|}
\hline 眞一 & 岡島 & 邦雄 & 磯崎 \\
\hline 英二 & 北出 & 俊一 ${ }^{*}$ & 小溝 \\
\hline
\end{tabular}

胃癌手術の合理化のための指標の1つとして, 術前画像診断によるリンパ節転移の猃断能につき検

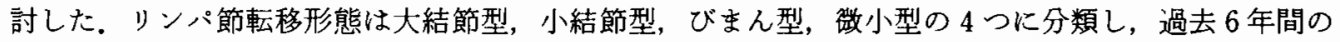
$\mathrm{R}_{2}$ 以上の郭清を施行した 515 例を対象として臨床病理学的解析を行うとともに, 206例の ECHO, CT, MRIによる画像診断のリンパ節転移の診断特性を求めた。結果リンパ節転移形態別出現頻度は, 大結 節型 $27.0 \%$ ，小結節型 $16.9 \%$ ，びまん型 $54.0 \%$, 知 $2.1 \%$ 型びまん型が多い. またりンパ節の長径 は大結節型では転移陰性リンパ節より有意に大きかったが,他の転移形態では有意差を認めなかった。 画像診断によるリンパ節転移の正診率は，ECHO 55.6\%，CT $72.5 \%$ ，MRI 68.6\%で，リンパ節の 転移形態別に大結節型で良好であった。 また腹部大動脈周囲リンパ節の診断は MRI の冠状断像が有 効であった，以上から大結節型転移形態のみが術前画像診断により転移経路を想定した術式選択が可 能と考兄られた。

Key words: preoperative imaging diagnosis, rational surgery, mode of metastasis in the lymph node

はじめに

従来胃癌に対する根治手術として行われてきた定型 的あるいは拡大手術による成果にはめざましいものが

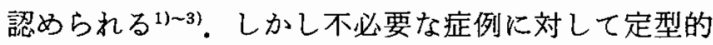
なまたは拡大手術を施行したり，逆に必要な症例に扗 大手術が行われない場合もあり合理性の面からは問題 が残ることが指摘されている。最近この面から早期胃 癌に対しては縮小の, 進行胃癌に対しては払大手術が 検討されている4)。この合理化を適切に行らためには, 占居部位, 深達度, 組織型などの臨床病理学的解析に 基づき術式の選択を行うと同時に，最近の画像診断機 器を駆使した正確な進行度判定を行ら必要性がある。 そこでリンパ節の転移形態分類による臨床病理学的解 析と ECHO, computed tomography (CT), magnetic resonance imaging（MRI）を用いたりンパ節転移の 診断能について検討し, 術前画像診断による術式選択 の可能性について検討した。

*第38回日消外会総会シンポ 1・術前診断からみた手 術術式の決定

<1991年11月20日受理>別刷請求先：山田 基一

干569 高梘市大学町 2-7 大阪医科大学一般・消化 器外科
対象と方法

リンパ節の転移形態による臨床病理学的解析は, 1985年 1 月より 1990年 12 月までの 6 年間の $\mathrm{R}_{2}$ 以上の 郭清を施行した515例を対象とした。この症例中リンパ 節転移は250例 $(48.5 \%)$ に認められた。またリンパ節 郭清個数は，25,075個で 1 症例あたり49個で，転移リ ンパ節は 2,759 個認められ, 転移陽性 1 例あたり 11 個の

リンパ節転移であった。

また ECHO，CT，MRIは同期間の206例を対象と し，診断能の特性を求めて検討した。

診断能の特性は，Bayesの定理 ${ }^{5}$ に基づき画像診断 および組織学的転移の有無により感度 (sensitivity) (組織学的リンパ節転移 (十) 群中画像診断にてリンパ 節転移 (十) と診断される率), 特異度 (specificity) (組織学的リンパ節転移 (一) 群中画像診断にてリンパ 節転移（一）である率），正診率（accuracy）（画像診 断上リンパ節転移 (十) と（一）が正しく判定される 率)を求めた。

各画像診断におけるリンパ節転移陽性との判定は, 辺縁の状態, 内部の性状, 形状を参考にして行った (Table 1).

リンパ節の転移形態の分類はFig. 1 に示したごと く, (1)大結節型：リンパ節全体が転移癌細胞により占 
Table 1 Assesment of the lymph node metastasis according to preoperative imaging diagnosis

\begin{tabular}{|c|c|c|c|}
\hline & $\mathrm{ECHO}$ & CT & MRI \\
\hline margin & $\begin{array}{l}\text { sharp or } \\
\text { irregular }\end{array}$ & $\begin{array}{l}\text { sharp or } \\
\text { irregular }\end{array}$ & $\begin{array}{l}\text { sharp or } \\
\text { irregular }\end{array}$ \\
\hline \multirow[t]{2}{*}{$\begin{array}{l}\text { internal } \\
\text { structure }\end{array}$} & rough $\mathrm{ECHO}$ & $\begin{array}{l}\text { low density } \\
\text { (no enhanced) }\end{array}$ & low signal \\
\hline & & $\begin{array}{l}\text { irregular high } \\
\text { at low density }\end{array}$ & $\begin{array}{l}\text { irregular high } \\
\text { at low signal }\end{array}$ \\
\hline shape & spherical & spherical & spherical \\
\hline
\end{tabular}

められ，リンパ節の固有構造がほとんど認められない 型, (2)小結節型：リンパ節の一部に 1 ～数個の転移癌 細胞の結節が認められるが，転移巣以外の部ではリン パ節の固有構造は保たれている型，(3)゙まん型：髄洞, 辺縁洞中に癌細胞がびまん性に存在するが，リンパ節 の固有構造は保たれている型, (4)微小型：1腺管程度 の癌胞巣または数個の転移癌細胞のみ認める型の 4 つ に分類した。

なお検定は Student's t-test を用い， $\mathrm{p}<0.05$ を有意 差とした。

\section{成 績}

1.リンパ節の転移形態分類による臨床病理学的解 析

1) リンパ節転移形態別出現頻度

転移リンパ節2,759個中大結節型745個 (27.0\%)，小 結節型は465個 (16.9\%)，びまん型は1,489個(54.0\%)， 微小型は60個（2.1\%）であった（Fig. 1).

2）リンパ節の群別リンパ節転移形態別出現頻度

第 1 群リンパ節 (378個) では，大結節型 $28.3 \%$ ，小

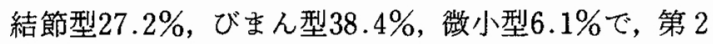

Fig. 1 Classification of mode of metastatic focus in the lymph node according to the microscopic finding type of metastasis number of the lymph node

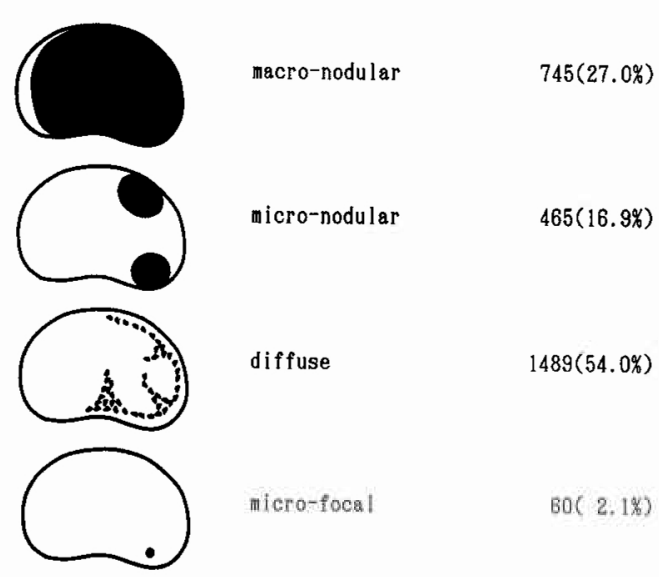

群リンパ節 (185個) では，大結節型 $24.3 \%$, 小結節型 $27.6 \%$,びまん型 $44.3 \%$, 微小型3.8\%と第 1 群リンパ 節とほぼ同様の分布を示した。第 3 群リンパ節 (67個) になると，大結節型 $40.3 \%$ ，小結節型 $14.9 \%$ ，びまん 型 $40.3 \%$, 微小型 $4.5 \%$ と大結節型の占める率が増加す る.一方第 4 群リンパ節（67個）になると大結節型 $23.9 \%$ ，小結節型 $19.4 \%$ ，びまん型 $41.8 \%$ ，微小型 $14.9 \%$ と大結節型は減少し, 微小型転移形態が増加し た (Fig. 2).

3）リンパ節の転移形態別長径の分布

転移陽性リンパ節の長径の平均は $4.4 \mathrm{~mm}$ で, ピーク は $3 \mathrm{~mm}$ である。これに対し大結節型では，平均 11.9 $\mathrm{mm}$, ピーク $10 \mathrm{~mm}$ で転移陰性リンパ節との差は推計

Fig. 2 Incidence of mode of metastatic focus in the lymph node according to the group of lymph node

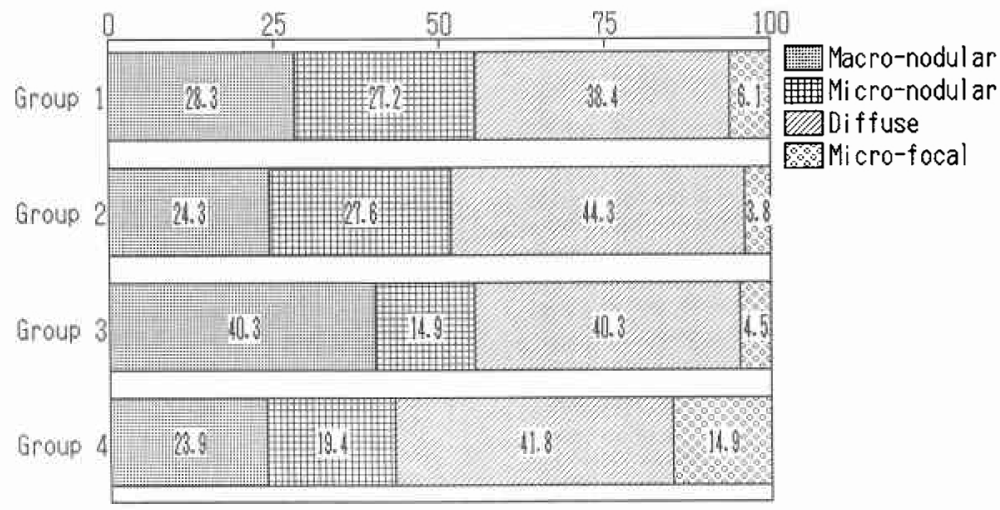


Fig. 3 Relationship between the diameter of lymph node and mode of metastatic focus in the lymph node

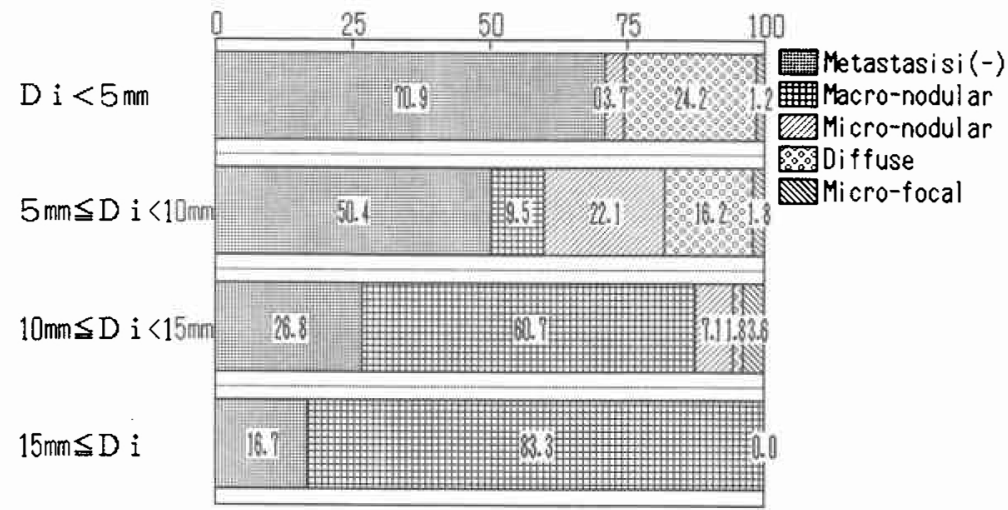

Table 2 The diameter of metastatic lymph node according to the mode of metastatic focus in the lymph node

\begin{tabular}{l|r|r}
\hline & \multicolumn{1}{|c|}{ Mean \pm SD } & \multicolumn{1}{c}{ Peak } \\
\hline Metastasis (-) & $4.4 \pm 2.9 \mathrm{~mm}$ & $3.0 \mathrm{~mm}$ \\
Macro-nodular & $11.9 \pm 6.0 \mathrm{~mm}$ & $10 \mathrm{~mm}$ \\
Micro-nodular & $6.5 \pm 2.1 \mathrm{~mm}$ & $4.1 \mathrm{~mm}$ \\
Diffuse & $4.1 \pm 2.0 \mathrm{~mm}$ & $3.0 \mathrm{~mm}$ \\
Micro-focal & $6.0 \pm 2.8 \mathrm{~mm}$ & \\
\hline
\end{tabular}

学的に有意 $(\mathrm{p}<0.05)$ であった。 また小結節型では平 均 $6.5 \mathrm{~mm}$, ピーク $6 \mathrm{~mm}$, びまん型では平均 $4.1 \mathrm{~mm}$, ピーク $3 \mathrm{~mm}$, 微小型では平均 $6 \mathrm{~mm}$ でピークは形成せ ず，この 3 転移形態の長径は転移陰性リンパ節と有意 差なく，とくにびまん型では，ほとんど大きさに変化 がなかった（Table 2).

4）リンパ節の長径別，転移形態別出現頻度

リンパ節の長径を $5 \mathrm{~mm}$ 間隔で区切った転移形態別 出現頻度は, 長径 $5 \mathrm{~mm}$ 末満（326個）では, 転移陰性 リンパ節が $70.9 \%$ 占め, 大結節型 $0 \%$, 小結節型 $3.7 \%$ ，びまん型 $24.2 \%$, 微小型 $1.2 \%$ とびまん型転移 形態を主とした転移りンパ節も約 $30.0 \%$ に認められ た. 長径 $5 \sim 9 \mathrm{~mm}$ では, 転移リンパ節は約 $50.0 \%$ に認 められる。 その転移形態は, 大結節型 $9.5 \%$, 小結節型 $22.1 \%$ ，びまん型 $16.2 \%$ ，微小型1.8\% と小結節型が主 体であった。長径10〜14mmでは転移リンパ節は約 $75 \%$ を占め, その転移形態は, 大結節型 $60.7 \%$, 小結 節型 $7.1 \%$, びまん型 $1.8 \%$, 微小型 $3.6 \%$ と大結節型が 主体である。さらに長径 $15 \mathrm{~mm}$ を越えると $85 \%$ が転移 リンパ節で, その転移形態は, すべて大結節型であっ
Table 3 Assesment of preoperative imaging diagnosis for the metastasis of lymph nodes

\begin{tabular}{l|c|c|c|c}
\hline & ECHO & CT & MRI & Final diagnosis \\
\hline sensitivity & $27.8 \%$ & $51.9 \%$ & $69.2 \%$ & $55.6 \%$ \\
specificity & $92.6 \%$ & $95.8 \%$ & $66.7 \%$ & $88.5 \%$ \\
accuracy & $55.6 \%$ & $72.5 \%$ & $68.8 \%$ & $68.3 \%$ \\
\hline
\end{tabular}

た (Fig. 3).

5）各画像診断に打けるリンパ節転移の診断能

ECHO, CT, MRI におけるリン八゚節転移の診断能お

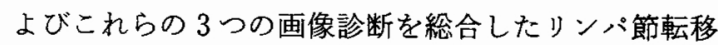
の診断能は, 組織学的にリンバ節転移 $(+)$ 群中画像 診断でもリンパ節転移 $(+)$ と診断される感度 (sensitivity)は, ECHO では27.8\%, CTでは $51.9 \%$, MRI

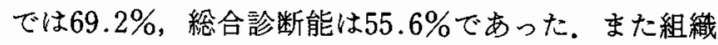
学的にリンパ節転移 (-) 群中画像診断でもリンパ節 転移 $(-)$ と判定される特異度 (specificity) は, ECHO では92.6\%, CT では $95.8 \%, \mathrm{MRI} て ゙ は 66.7 \%$ ，総合

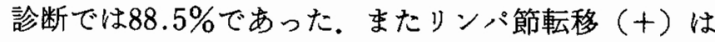
(十)，リンパ節転移転移（一）は（）と正しく判定 される正診率は，ECHO $55.6 \%$, CT $72.5 \%$, MRI $68.6 \%$, 総合診断 $68.3 \%$ あった（Table 3).

6）リンパ節転移の形態別診断能

リンパ節転移の形態別に, 総合診断における感度 (sensitivity) 求めると, 大結節型では $90.9 \%$ ，小結

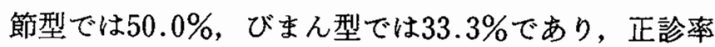

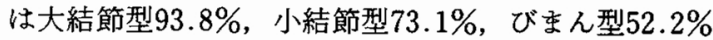
で，大結節型とびまん型とでは推計学的に有意 $(\mathrm{p}<$ 0.05）であった（Table 4).

7）腹部大動脈周囲リンパ節転移の診断能 
Table 4 Assesment of preoperative imaging diagnosis according to the mode of metastatic focus in the lymph node

\begin{tabular}{l|c|c|c}
\hline & Macro-nodular & Micro-nodular & diffuse \\
\hline sensitivity & $90.9 \%$ & $50.0 \%$ & $33.3 \%$ \\
specificity & $95.2 \%$ & $87.5 \%$ & $72.7 \%$ \\
accuracy & $93.8 \%$ & $73.1 \%$ & $52.2 \%$ \\
\hline
\end{tabular}

Macro-nodular vs Micro-nodular $\mathrm{p}<0.05$

Table 5 Assesment of preoperative imaging diagnosis for the metastasis of lymph nodes to abdominal para-aorta

\begin{tabular}{l|c|c|c}
\hline & ECHO & CT & MRI \\
\hline sensitivity & $25.0 \%$ & $38.8 \%$ & $50.0 \%$ \\
specificity & $90.9 \%$ & $88.5 \%$ & $90.9 \%$ \\
accuracy & $59.5 \%$ & $68.2 \%$ & $73.7 \%$ \\
\hline
\end{tabular}

各画像診断別に腹部大動脈周团リンパ節転移の診断 能を比較すると, 感度 (sensitivity)は, ECHO 25.0\%, CT $38.8 \%$, MRI 50.0\%で, 特異度（specificity）は, ECHO $90.9 \%$, CT $88.5 \%$, MRI $90.9 \%$, 正診率 (accuracy) は, ECHO 59.5\%, CT $68.2 \%$, MRI 73.7\%と MRIが高かった（Table 5).

\section{考 察}

近年, 胃癌手術に関して, 合理化が重要な課題とし て取り上げられ, 早期胃癌に対しては縮小の, 進行胃 癌に対しては拡大の方針が検討されている6).

これら合理化を適切に押し進めるためには, 術前の 深達度, 占居部位, 組織型等の臨床病理学的事象の解

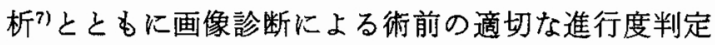
が重要となる。教室に乱ける過去 12 年間の $\mathrm{R}_{2}$ 以上の郭 清を施行した985例を早期癌368例, 進行癌617例にわ け，郭清の程度とリンパ節転移の程度を検討すると， 郭清の程度がリンバ節転移の症例よりも $1 \sim 2$ 段階上 回り retrospective に合理的手術が施行されたと考え られる率は, 早期癌では $9.0 \%$, 進行癌では $42.7 \%$ にし かすぎない.リンパ節転移陰性例に対し $\mathrm{R}_{2}, \mathrm{R}_{3}$ とい。 た定型的な手術が旋行された群は，早期癌で $89.1 \%$, 進行癌で $27.9 \%$ で, 逆に郭清の程度が組織学的リンパ 節転移の程度と同等または下回り, 郭清不十分と考兄 られる率は，早期癌1.9\%, 進行癌 $29.3 \%$ であった。術 前画像診断の精度が向上すれば，転移陰性例に対し過 度な郭清を行ったり，また逆に転移陽性例に対し郭清
不十分となる率は減少させることが可能となる。しか しリンパ節の転移形態と長径の検討結果からは, 転移 陰性リンパ節と比べ有意に長径が大きかったのは大結 節型の転移形態のみであった。現在画像診断における リンパ節転移陽性との判定に長径の増大が大きな根拠 となっている．実際長径 $10 \mathrm{~mm}$ 以上のリンパ節を認め

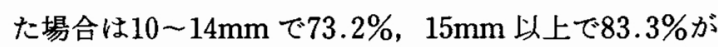
転移陽性リンパ節であり，術前診断には参考となる。 しかし10mmをこえる率はリンパ節全体の $11.9 \%$ にし かすぎず， $10 \mathrm{~mm}$ 以下のリンパ節の転移の有無を診断 することが正診率向上にとって重要であり，リンパ節 転移の診断根拠を長径におくかぎり画像診断のリンパ 節転移に対する限界は低いといわざるをえない，

リンパ節転移の診断向上のために，CT では enhanced CT の併用と脂肪乳剤の服用を ${ }^{8)}$, MRI では横断 像に加冠状断像を併用して施行しているが，とくに MRI に括ける腹部大動脈の level の冠状断像は, 腹部 大動脈周团の高信号の脂肪の中に低信号のリンパ節が 描出され，腹部大動脈周囲リンパ節転移の診断には有 効と考克られる。

脂肪乳剤を服用させる胃のCT 検査では，胃壁を はっきりと認識させ, 周团組織との位置関係を描出さ せるため，リンパ節を同定しやすくする，同じ理論で MRIV怙いても空気が同じ役割を果たすため撮影時 に胃内に充満させて招く之読影が容易になる。また MRIでは脂肪は高信号をだすため, 脂肪織が豊富な部 位では低信号のリンパ節との contrastにより読影し やすくなる.とくに冠状断像における腹部大動脈周囲 リンパ節は大動脈周囲の脂肪層の高信号域のなかに,

低信号のリンパ節が描出されるため, 長径 $5 \mathrm{~mm} \sim 10$ $\mathrm{mm}$ でも確認できる。

一般に転移の有無の診断は, 内部構造の鮮明な描出 に負うところ大である. MRIの欠点は，数分以上の撮 影時間を要するため mortion artifactによる画質の低 下で9，とくに上腹部では呼吸と心拍による影響が大 である。今後撮影時間の高速化と呼吸，心拍同期シス テムの改良, 応用ができれば10),さらに診断精度が向上 するであろう。

以上から術前画像診断により術式選択の可能性とし ては, 大結節型転移形態を呈する場合, 画像診断によ る正診率は良好で，その転移部位から転移経路を想定 した郭清の合理化は可能と考えられる。一方，びをん 型や微小型転移形態の存在から, 転移陰性の診断は困 難であり, 深達度, 組織型, 占居部位などの臨床病理 


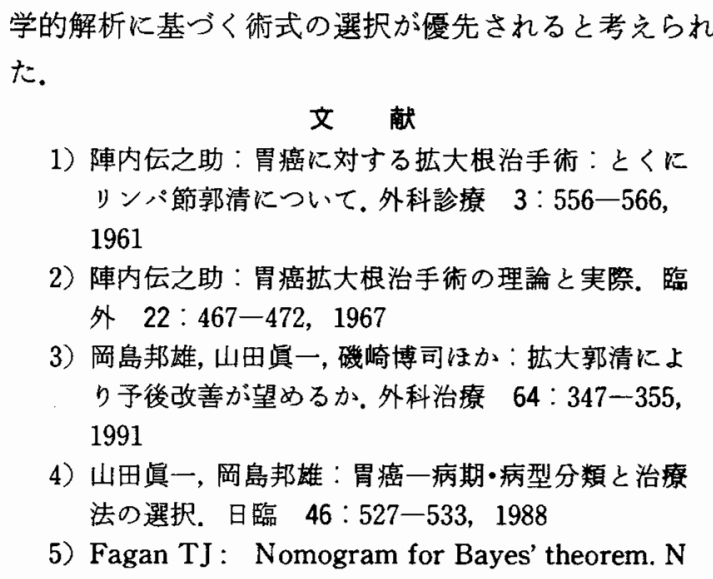

Engl J Med $298: 257-260,1975$

6）岡島邦雄, 山田䢐一, 磯崎博司：胃癌治療に拈ける 日本の現状。手術 44：1361-1366，1990

7) 山田貞一, 磯崎博司, 中島立博ほか: 病期・組織型 からみた胃癌治療の選択. 癌治療・今日と明日 $12: 27-30,1990$

8）松井昭彦, 岡島邦雄, 富士原彰はか：脂肪乳剂注入 法を用いたCT 像による胃癌の壁深達度診断。日 臨外医会誌 $47: 1181-1190,1986$

9）植松貞夫, 岡田淳一, 守田文範注か：MRIモー ション・フーチフフクトの除去と呼吸・心拍同期シ ステム。 日湢 $45: 21-25,1987$

10）真野 勇, 吉田英夫, 八代直文注か：MRI 高速化 に上る腹部診断能の向上. 日臨 $45: 15-20,1986$

\title{
Studies of Preoperative Imaging Diagnosis for the Assessment on the Lymph Node Metastasis of Gastric Cancer
}

\author{
Shinichi Yamada, Kunio Okajima, Hiroshi Isozaki, Eiji Nakata, Toshikazu Kitade* and Yoshimi Komizo* \\ Department of Surgery, Osaka Medical College \\ Kitade Hospital for Gastro-Intestinal Disease*
}

To allow a more rational selection of a surgical procedure for gastric cancer, taking into consideration the features of lymph node metastasis, we recently assessed the usefulness of imaging techniques in the preoperative diagnosis of lymph node metastasis. Lymph node metastasis of gastric cancer was divided into four types: micronodular, diffuse and micro-focal. By using this classification, a clinicopathological analysis was conducted on 515 patients who had undergone $R_{2}$ or more extensive lymph node dissection over the past 6 years. In 206 of these patients, the findings of ultrasonography, computed tomography (CT) and magnetic resonance imaging (MRI) before the operation were compared. Of all cases of lymph node metastasis, $27.0 \%$ were of the macro-nodular type, $16.9 \%$ the micro-nodular type, $54.0 \%$ the diffuse type and $2.1 \%$ the micro-focal type. The largest diameter of the lymph nodes affected by macro-nodular type metastasis was significantly greater than that of the metastasis-free lymph nodes, while this parameter did not significantly differ between the lymph nodes showing the other types of metastasis and the metastasis-free lymph nodes. The rate of accurate diagnosis of lymph node metastasis was $55.6 \%$ with ultrasonography, $72.5 \%$ with CT and $68.6 \%$ with MRI. The rate was particularly high for nodular type metastasis. For the diagnosis of metastasis to the lymph nodes of the abdominal para-aorta, MRI of the coronal sections was useful. These findings indicate that only the macro-nodular type lymph node metastasis can be accurately diagnosed by imaging before the operation, requiring the rout of cancer metastasis to be appropriately considered in selecting a surgical procedure for gastric cancer.

Reprint requests: Shinichi Yamada Department of Surgery, Osaka Medical College 2.7 Daigaku-cyo, Takatsuki, 569 JAPAN 